\title{
MARX E O FETICHE DA MERCADORIA DINHEIRO
}

Jadir Antunes $^{1}$

\begin{abstract}
Resumo:
Nosso artigo pretende mostrar que a crítica do fetiche da mercadoria em Karl Marx deve ser associada à crítica metafísica da mercadoria porque, segundo Marx, uma das características centrais da metafísica é a inversão dos polos concreto e abstrato e sensível e suprassensível em prol da autonomização do abstrato e do suprassensível e sua conversão em polos absolutos. Assim como na Metafísica e na religião cristã a ideia-abstrata e o deus-abstrato dominam o concreto e o sensível da vida humana, no mercado a riqueza-abstrata do dinheiro domina o mundo da riqueza concreta e sensível diariamente consumida pelo homem.
\end{abstract}

Palavras-chaves: Karl Marx (1818-1883). Fetiche da mercadoria. Crítica da metafísica.

\section{MARX AND THE FETISHISMUS OF MONEY-COMMODITY}

\begin{abstract}
:
Our article intends to show that the critique of the commodity fetishism in Karl Marx must be associated with the metaphysical critique of the commodity because, according to Marx, one of the central characteristics of metaphysics is the inversion of the concrete and abstract and sensible and suprasensible poles for the benefit of autonomization the abstract and the suprasensible poles and its conversion into absolute poles. Just as in Metaphysics and in the Christian religion the abstract idea and the abstract god dominate the concrete and the sensible of human life, in the market the abstract wealth of money dominates the world of the concrete and sensible wealth daily consumed by man.
\end{abstract}

Keywords: Karl Marx (1818-1883). Fetishismus of commodity. Criticism of metaphysics.

\section{Apresentação}

Hegel lamentava, em 1812, no Prefácio à Primeira Edição de sua Ciência da Lógica, a transformação sofrida pelo pensamento e o interesse perdido pela Metafísica como ciência no início do século XIX na Alemanha. Segundo Hegel, a nova ciência daqueles tempos renunciara ao pensar especulativo, ao pensar do absoluto enquanto absoluto, e adotara o pensar cotidiano do homem comum, o pensar do sensível e da experiência, que não se pode chamar propriamente de pensar. Hegel lamentava o desaparecimento daquele homem de espírito especulativo, solitário e segregado do mundo, devotado exclusivamente à contemplação e ao pensamento do eterno e o surgimento de um homem moderno de espírito meramente prático e dedicado inteira e unicamente à investigação do ser-aí. Em vão, porém, lamentou Hegel a morte da metafísica e do pensamento, pois, sem que soubesse, a metafísica permanecia viva e atuante em sua época, como ainda permanece, nas obras da mão humana, nas obras do capital, da mercadoria e da paixão por dinheiro.

1 Professor do Programa de Pós-graduação em Filosofia da Unioeste - PR. Email: jdiant@ yahoo.com.br. Endereço eletrônico do Curriculum Lattes: http://lattes.cnpq.br/1904038403983877. 
Marx sempre foi um grande crítico da metafísica e da alienação religiosa não apenas em sua juventude, mas, sobretudo, em sua época madura e adulta. A diferença entre o Marx da juventude, o Marx jovem hegeliano de esquerda influenciado pelas críticas radicais de Feuerbach, e o Marx da maturidade, o Marx do Capital, especialmente, consiste em que o jovem Marx ocupavase da crítica às metafísicas do pensamento e do sentimento, às metafísicas filosófica e religiosa, enquanto o velho Marx se ocupará, essencialmente, da crítica à metafísica das mãos, à crítica da metafísica da produção e do mercado, à crítica da ciência metafísica da produção, à Crítica da Economia Política, à crítica do que se convencionou chamar de fetiche da mercadoria.

A crítica madura de Marx à Economia Política deve ser interpretada de maneira mais crítica, mais radical, mais ampla e filosófica como Crítica da Metafísica Moderna, da metafísica agora encarnada não mais nas obras do pensamento e da fé, mas nas obras das mãos, do mercado, da mercadoria, do dinheiro e do capital. Toda a crítica madura de Marx aos economistas se reduz, no fundo, a uma crítica da metafísica encarnada na figura dinheiro, pois o dinheiro aparece agora nas relações de troca como figura metafísica mesmo, como corpo encarnado, como essência objetivada, como forma de manifestação, como representação de algo distinto dele próprio, de algo que não é ele mesmo, de algo que se esconde para além de sua própria corporalidade concreta e sensível, de algo que o determina e o fundamenta, de algo que está invisível e oculto no interior dos corpos das mercadorias, de algo abstrato e suprassensível que não se mostra a si mesmo enquanto tal, de algo que só pode se manifestar numa relação de troca com outra mercadoria, de algo genérico, abstrato e indeterminado chamado valor da mercadoria que precisa, necessariamente, se manifestar de maneira estranhada e alienada no corpo de uma coisa sensível e real chamada dinheiro.

O mistério do dinheiro, o fetiche da mercadoria dinheiro, consiste, portanto, no mistério da metafísica, no mesmo mistério que domina as produções da mente humana, como os mistérios da Filosofia e da Religião. Desvendar, expor e denunciar os mistérios do dinheiro significa, assim, ao mesmo tempo, desvendar, expor e denunciar os mistérios da metafísica e de como esta metafísica, que já dominava as obras do sentimento e da mente humana, domina também, ferreamente, as obras da mão humana.

A luta e a denúncia de Marx em sua juventude contra a Metafísica aparecem agora, em O Capital e na sua crítica ao dinheiro, como a luta contra a Economia Política e ao modo de vida

\begin{tabular}{|c|c|c|c|c|}
\hline Qenista Oialectus & Ano 5 & n. 12 & Janeiro - Julho 2018 & p. $139-162$ \\
\hline
\end{tabular}


dominante do capitalismo, o modo de vida dominado por um ente absoluto e sagrado chamado dinheiro, o Leviatã do mercado, por um ente que agora encarna todos os poderes gerais da humanidade e se apresenta diante desta mesma humanidade como figura independente e autonomizada, como seu senhor e déspota absoluto.

O dinheiro domina o mundo manual humano do mesmo modo como a Metafísica domina o mundo intelectual, através da prática da negação, da abstração, da renúncia, da hipostasiação e da racionalização total dos entes. O dinheiro, como mostra Marx, é a negação completa da riqueza enquanto riqueza concreta, prestável e sensível em nome de uma riqueza abstrata, hipostasiada, não sensível e não prestável ao homem. Assim como ocorre na Metafísica e na Religião, o dinheiro é a negação do sensível e do concreto da realidade humana em nome de uma realidade suprassensível, abstrata, genérica e estranhada: a realidade do valor e da determinação genérica e abstrata do trabalho humano.

Assim como a Metafísica e a Religião dominam a vida intelectual moderna com seus conceitos e categorias abstratas e em direta oposição à vida vivida e experimentada pelos sentidos, também o dinheiro domina a vida manual e animal do homem com seus conceitos e categorias abstratas, tais como mercadoria, trabalho, valor, dinheiro, preço, salário, lucro, capital e em direta oposição às determinações da riqueza enquanto coisa concreta, sensível, natural, prestável e consumível na vida diária do homem comum.

Para compreender o chamado problema do fetiche da mercadoria como o problema da metafísica da mercadoria e, especialmente, da mercadoria dinheiro, será necessário perceber como a terminologia empregada por Marx na maturidade e em $O$ Capital, especialmente, é uma terminologia oriunda inteiramente da Filosofia, especialmente de sua vertente Metafísica, como o movimento lógico e categorial presente nas categorias abstratas da filosofia é, num grande sentido, o mesmo movimento lógico e categorial das categorias da economia, como sua crítica à metafísica da mercadoria é realizada inteiramente no interior dos próprios paradoxos e contradições da mesma metafísica, e como só podemos compreender totalmente o problema do fetiche da mercadoria a partir da Filosofia e da crítica à Metafísica como ciência e não a partir das mais variadas disciplinas oriundas das Ciências Humanas, como a Antropologia e a Psicologia especialmente.

Assim, ainda que Marx afirme que o fetiche da mercadoria deveria ser mais bem compreendido a partir da comparação com o fetiche da religião, a religião da qual fala Marx não é a

\begin{tabular}{|l|l|l|l|l|}
\hline Q Revista Dialectus & Ano 5 & n. 12 & Janeiro - Julho 2018 & p. 139-162 \\
\hline
\end{tabular}


religião primitiva, animista e panteísta dos povos antigos, mas a religião cristã, a religião do além, do deus revelado, do deus abstrato, pessoal, transcendente e alienado que tem como fundamentos a estrutura, a arquitetura e a terminologia metafísica oriundas da Filosofia.

\section{O primeiro movimento da mercadoria}

Para compreendermos o fetiche da mercadoria será necessário compreendermos o duplo movimento da mercadoria: o movimento do vir-a-ser mercadoria e o do vir-a-ser dinheiro. $\mathrm{O}$ primeiro movimento da mercadoria, o do vir-a-ser mercadoria, é o movimento através do qual uma coisa, que em sua origem existe em-si e por-si mesma, torna-se mercadoria e coisa para outro numa relação de troca. A mercadoria [Ware] não é uma coisa, ao contrário da riqueza concreta e sensível representada pelo valor-de-uso [Gebrauchswert], mas uma relação, uma relação de troca com outra mercadoria, e só existe nesta relação. Fora da relação de troca com outra coisa a coisa tem uma existência em-si e por-si-mesma como valor-de-uso. É somente na relação de troca que a coisa passa-a-ser mercadoria. A mercadoria, portanto, diferentemente do valor-de-uso que tem uma existência absoluta, tem uma existência meramente dependente e relativa.

A mercadoria é o ente negado e abstrato da troca, porque para ser posta numa relação de troca a coisa precisa, em primeiro lugar, não ser valor-de-uso para seu próprio possuidor direto, mas valor-de-uso para outro, e, em segundo lugar, para ser aceita numa relação de troca, ambas as coisas trocadas precisam abstrair suas diferenças reais, concretas e sensíveis e se relacionar entre si como coisas abstratamente iguais, como coisas suprassensíveis portadoras de uma única e mesma substância comum, como quando linho e casaco são permutados na troca como coisas abstratamente iguais entre si.

Por ser a forma originária, natural e absoluta da riqueza, o valor-de-uso é a forma ontológica da riqueza, enquanto a mercadoria é sua forma alienada, cindida e metafísica. Como diz Marx em Para a Crítica da Economia Política:

Ser valor-de-uso parece ser pressuposto necessário [notwendige Voraussetzung] para a mercadoria, mas não reciprocamente, pois ser mercadoria parece ser determinação indiferente [gleichgültige Bestimmung] para o valor-de-uso. ${ }^{2}$

2 Karl Marx: Para a Crítica da Economia Política. Coleção Os Pensadores. São Paulo: Nova Cultural, 1987, pp. $35 / 36$. Karl Marx/Friedrich Engels - Werke. Band 13-7. S. 49-160. Berlin: Dietz Verlag, 1971, p. 16.

\begin{tabular}{|l|l|l|l|l|}
\hline Revista Dialectus & Ano 5 & n. 12 & Janeiro - Julho 2018 & p. 139-162 \\
\hline
\end{tabular}


Por ser seu pressuposto, o valor-de-uso é indiferente à existência da mercadoria. Nesta indiferença com a mercadoria, o valor-de-uso é "valor-de-uso em si mesmo" [Gebrauchswert als Gebrauchswert $]^{3}$, diz Marx. Assim, enquanto o valor-de-uso é a diferença indiferente da riqueza a mercadoria é a diferença não indiferente. $\mathrm{O}$ valor-de-uso, portanto, em sua determinação ontológica é condição de existência para a mercadoria. A metafísica da troca, porém, inverte esta relação entre os termos e transforma a forma suprassensível e não natural da riqueza em condição de existência para a forma ontológica, sensível e natural, já que uma vez que a mercadoria torna-se a forma dominante da riqueza, para ser valor-de-uso social e efetivo será necessário antes ser mercadoria. No mundo da mercadoria a coisa só será vista como coisa útil se for mercadoria. A metafísica transforma, assim, a independência e a indiferença originárias do valor-de-uso em dependência e não indiferença.

O mundo da mercadoria, portanto, é um mundo cindido, duplicado, antinatural, invertido e contraditório. Neste mundo cindido, a metafísica inverte os polos da relação, convertendo, misticamente, a mercadoria no ser absoluto, em si e para si, e o valor-de-uso no ser relativo e dependente, no ser que depende do ser mercadoria para ser útil e prestável ao ente humano. No mundo natural, para ser valor-de-uso não é necessário ser mercadoria e valor-de-troca. No mundo metafísico e invertido da mercadoria, porém, para ser valor-de-uso é necessário ser, contraditoriamente, não-valor-de-uso, é necessário ser mercadoria e valor-de-troca [Tauschwert]. Metafisicamente falando, para ser, a coisa precisa, paradoxalmente, não-ser.

Ser valor-de-uso, como ser casaco, é ser a forma natural e eterna da riqueza, é ser a forma permanente, absoluta e essencial dela. Ser mercadoria, por outro lado, é ser não natural e não essencial. A metafísica, porém, inverte espantosamente os polos do essencial e do não essencial da riqueza, tornando o ser verdadeiramente essencial, o valor-de-uso, em ser não essencial, e o ser não essencial, o valor-de-troca, no ser essencial. Assim, com a metafísica da troca, o valor-de-uso, a forma ontológica, natural e útil da riqueza, deixa de ser a forma verdadeira e essencial da riqueza para dar lugar ao valor-de-troca, a forma não verdadeira e passageira dela.

3 Para a Crítica da Economia Política, p. 36. MEW 13-7, p. 16.

\begin{tabular}{|c|c|c|c|c|}
\hline Gevista Dialectus & Ano 5 & n. 12 & Janeiro - Julho 2018 & p. $139-162$ \\
\hline
\end{tabular}


$\mathrm{Na}$ base das relações de troca se desenvolve, então, um permanente conflito entre a forma útil, verdadeira, essencial, sensível e natural da riqueza e sua forma não útil, não essencial, suprassensível e social. Nesse conflito, o valor-de-uso da mercadoria representa a riqueza em sua forma sensível e natural, e o valor-de-troca a sua forma suprassensível, social e, sobretudo, autonomizada. Por isso, como a forma sensível e natural e a forma suprassensível e social da riqueza estão metafisicamente cindidas, será fundamental que a forma natural se converta antes em dinheiro para que se converta em forma social da riqueza. Sem essa conversão, os produtos não chegam até as mãos da sociedade e seu valor-de-uso natural é desperdiçado.

Como o mundo da mercadoria é um mundo metafisicamente cindido e invertido, como os diferentes produtores individuais estão isolados e separados entre si pela divisão social do trabalho criada pela mercadoria, como os produtos destes diferentes produtores não se apresentam mais em sua forma natural e sensível como imediatamente utilizáveis, este mundo cindido e separado precisará ser reunido e unificado por um elemento metafísico comum a todos estes mundos, por um ente suprassensível chamado dinheiro. O dinheiro aparecerá diante dos sentidos destes produtores divididos e alienados entre si como aquele ente sagrado e poderoso, como aquele ente extraordinário capaz de operar a redução metafísica da multiplicidade à unidade e da diferença à igualdade.

Essa coisa chamada mercadoria possui, portanto, uma "dupla forma" [Doppelform] ${ }^{4}$, uma "dupla existência" [Doppelexistenzen] $]^{5}$ e um "duplo ser" [Doppeldasein] ${ }^{6}$. Por um lado, essa coisa possui a forma sensível e natural de ser valor-de-uso [Naturalform] que satisfaz determinada necessidade humana fora e independentemente de ser posta numa relação de troca e, por outro, possui a forma suprassensível e social de ser valor para outro na relação de troca [Wertform] ${ }^{7}$.

De coisa simples e ordinária, a mercadoria passa a ser, então, "uma coisa muito complicada, cheia de sutileza metafísica e manhas teológicas" [voll metaphysischer Spitzfindigkeit und theologischer Mucken] $]^{8}$. Por isso, logo que uma coisa aparece como mercadoria, ela se

4 Karl Marx: O Capital: crítica da economia política. Livro I. Volume I. Tradução de Regis Barbosa e Flávio R. Kothe. $3^{a}$ edição. São Paulo: Nova Cultural, 1988, p. 53. Karl Marx \& Friedrich Engels: Werke [Band 23]. Berlin: Dietz Verlag/DDR, 1962, p. 62.

5 Para a Crítica da Economia Política, pp. 66 e 67. MEW 13-7, p. 53.

6 Para a Crítica da Economia Política, pp. 66 e 67. MEW 13-7, p. 53.

7 O Capital - Volume I, p. 53. MEW 23, p. 62.

8 O Capital - Volume I, p. 70. MEW 23, p. 85.

\begin{tabular}{|l|l|l|l|l|}
\hline Q Rovista Dialectus & Ano 5 & n. 12 & Janeiro - Julho 2018 & p. 139-162 \\
\hline
\end{tabular}


transforma numa “coisa sensível suprassensível” [sinnlich übersinnliches Ding], ${ }^{9}$ diz Marx, pois o ente mercadoria aparece como o ente duplicado, cindido, negado e abstrato da riqueza.

Deste modo, através das tramoias da metafísica, diz Marx, "os produtos do trabalho se tornam mercadorias, coisas sensíveis suprassensíveis ou sociais" [sinnlich übersinnliche oder gesellschaftliche Dinge $]^{10}$. Os produtos sensíveis da mão humana, como nos produtos suprassensíveis da mente religiosa, aparecem, então, sob uma "forma fantasmagórica" [die phantasmagorische Form] ${ }^{11}$. A esta duplicação em sensível e suprassensível, natural e social, concreto e abstrato, e a inversão dos polos essenciais da relação, Marx dá, então, o nome de "fetichismo" [Fetischismus $]^{12}$.

\section{O segundo movimento da mercadoria}

O segundo movimento da mercadoria é aquele através do qual a coisa, que já havia se transformado em mercadoria, torna-se agora dinheiro. Vimos que ontologicamente a mercadoria nasce da alienação e da negação da coisa como valor-de-uso para seu próprio possuidor para vir-aser valor-de-uso para outro numa relação de troca. Para haver troca, porém, ambas as coisas precisam ser, em primeiro lugar, real e sensivelmente distintas entre si, já que não se trocam casaco por casaco, mas casaco por alguma coisa diferente; em segundo lugar, estas coisas real e sensivelmente diferentes precisam possuir algo em comum que as equipare e as equalize entre si, tornando a troca uma relação entre equivalentes. A equivalência entre as coisas trocadas pressupõe, assim, em primeiro lugar, a negação e a abstração total e completa destas diferenças reais e sensíveis de ambas as coisas trocadas; em segundo lugar, a relação de troca pressupõe a existência de uma substância igual e comum que equalize ambas as mercadorias como coisas de idêntico valor. A esta substância comum, igual, abstrata, genérica e suprassensível entre as mercadorias Marx dá o nome de valor [Wert].

O valor, portanto, é uma substância interna e comum às mercadorias trocadas, é a substância genérica e abstrata que permite que as mercadorias se relacionem entre si como abstratamente iguais. Esta igualdade genérica e abstrata entre as mercadorias é nada mais do que

9 O Capital - Volume I, p. 70. MEW 23, p. 85.

10 O Capital - Volume I, p. 71. MEW 23, p. 86.

11 O Capital - Volume I, p. 71. MEW 23, p. 86.

12 O Capital - Volume I, p. 71. MEW 23, pp. 86/87.

\begin{tabular}{|c|c|c|c|c|}
\hline Qonista Dialectus & Ano 5 & n. 12 & Janeiro - Julho 2018 & p. $139-162$ \\
\hline
\end{tabular}


certa quantidade de trabalho socialmente necessário para sua fabricação e preparo para o consumo, é nada mais do que certo dispêndio de trabalho e energias humanas medido no tempo. Duas mercadorias podem ser trocadas entre si numa relação de igualdade e equivalência, portanto, porque possuem a mesma quantidade desta substância abstrata comum, porque custaram o mesmo tempo de trabalho e o mesmo gasto de energias humanas na sua produção e preparação para o consumo. Esta substância comum e abstrata chamada tempo e valor contida na mercadoria, ao contrário do valor-de-uso que é uma coisa sensível e visível aos sentidos humanos, é uma coisa não visível e não sensível, é uma coisa abstrata e indeterminada.

Contudo, ainda que as mercadorias sejam trocadas entre si numa relação de equivalência medidas por esta substância chamada valor, o quantum de tempo contido em ambas as mercadorias é uma medida inteiramente invisível e desconhecida para os agentes da troca. Por este motivo, ainda que esta substância comum, abstrata e invisível regule todas as relações de troca como troca entre equivalentes, o dinheiro na forma de uma coisa, sensível, corpórea e material, será desenvolvido e posto pelo próprio mundo da mercadoria como a medida visível e sensível do valor equivalente entre elas. Neste movimento o dinheiro, na forma de coisa com a qual todas as mercadorias são medidas e trocadas, torna-se o valor-de-troca fundamental e efetivo da mercadoria, torna-se a forma de manifestação, ou forma fenomênica [Erscheinungsform] do valor e modo de expressão [Ausdrucksweise] visível do valor das mercadorias ${ }^{13}$.

Valor-de-uso [Gebrauchswert] e valor [Wert], assim como valor-de-uso e mercadoria [Ware], são elementos absolutamente opostos entre si. Entre ambos não há nenhuma relação de determinação e condicionamento mútuo. O valor, a substância comum e abstrata da mercadoria, é a antítese, a abstração e a negação direta e absoluta do valor-de-uso. A única relação que existe entre ambos é a de condição e exclusão recíproca. O valor-de-uso é a condição primária para a existência do valor, sem valor-de-uso, sem utilidade, nenhuma coisa pode vir a ser valor, mas não é, de modo algum, o fundamento ou a arkhé de onde se origina o valor. Por serem determinações antitéticas, por ser um a abstração do outro, ambos se excluem e se negam mutuamente. Nem um nem outro se apresentam como o fundamento e a arkhé ou como o modo de existência e manifestação do outro. Ambos, ainda, não se condicionam reciprocamente, mas apenas unilateralmente. Assim, o valor-de-

13

O Capital - Volume I, p. 46. MEW 23, p. 51.

\begin{tabular}{|c|c|c|c|c|}
\hline Rovista Dialectus & Ano 5 & n. 12 & Janeiro - Julho 2018 & p. $139-162$ \\
\hline
\end{tabular}


uso é condição para a existência do valor, mas, o valor não é, de modo algum, inversa e reciprocamente, do mesmo modo que na relação entre valor-de-uso e mercadoria, condição para a existência do valor-de-uso. O valor-de-uso da riqueza é total e inteiramente independente do valor. A existência da forma sensível e natural da riqueza é total e inteiramente independente de sua forma suprassensível e social.

Entre o valor [Wert] e o valor-de-troca [Tauschwert], porém, a relação é muito diferente. Um aparece como o fundamento invisível enquanto o outro aparece como a objetivação, a encarnação, a manifestação e o fenômeno visível deste fundamento. Entre ambos há mais que uma relação de condicionamento e determinação, entre ambos há uma típica relação reflexiva, metafísica, fetichista e sobrenatural [übernaturlich], pois enquanto o valor é uma Gehalt, um conteúdo, o valor-de-troca é uma mera Erscheinungsform, uma mera forma de manifestação e encarnação visível da substância valor. Enquanto o valor tem certa existência absoluta, ainda que somente em si, abstrata e potencialmente no interior da mercadoria, o valor-de-troca não possui qualquer existência fora da relação de troca de uma mercadoria com outra.

A mercadoria, o valor-de-troca e o valor não são desdobramentos ou formas desenvolvidas do valor-de-uso, não são uma espécie de dobras metafísicas contidas potencialmente no interior da riqueza em sua forma natural que se desdobram dialeticamente no tempo e para fora do em-si da riqueza sensível. Como dissemos, entre o valor-de-uso e a forma mercadoria da riqueza não existe nenhuma relação de determinação e fundamentação. A mercadoria não é a forma desdobrada, desenvolvida e superior do valor-de-uso, mas sua abstração e negação pelo ato da troca. O contrário, porém, ocorre com o valor e o valor-de-troca, onde este último, sim, aparece no mundo como a forma visível, exterior e desdobrada do valor, de uma coisa que está oculta, na forma do em-si, imersa e dobrada no interior da mercadoria.

O valor-de-uso de uma coisa é uma qualidade sensível, concreta e visível que se manifesta diretamente aos sentidos humanos fora de qualquer relação de troca com outra coisa. $\mathrm{O}$ valor, porém, por ser uma substância social, genérica, abstrata, suprassensível e não visível precisa ser posto numa relação de troca com outra coisa para se manifestar. Nesta relação, porém, o valor aparece metafisicamente encarnado no corpo do valor-de-troca e como se fosse o valor-de-troca.

O valor-de-uso possui uma existência totalmente absoluta e atual em relação tanto ao valor quanto ao valor-de-troca. O valor, por sua vez, possui certa existência absoluta somente em

\begin{tabular}{|l|l|l|l|l|}
\hline Q Rovista Dialectus & Ano 5 & n. 12 & Janeiro - Julho 2018 & p. 139-162 \\
\hline
\end{tabular}


relação ao valor-de-troca, uma existência abstrata e potencial, mas que depende, por outro lado, da forma valor-de-troca para ser valor efetiva e atualmente. O valor-de-troca, por sua vez, não possui qualquer realidade própria, sendo mera forma acidental e passageira da riqueza, mera forma de manifestação de um ente que só tem realidade quando condicionado à realidade de outro ente - o valor-de-uso. Enquanto o valor-de-uso tem uma existência em si assegurada fora de qualquer relação de troca, o valor só garante sua existência na relação de troca e em relação ao valor-detroca, em relação à sua forma de manifestação e existência real e atual chamada dinheiro. Com a metafísica e a inversão que lhe é própria, porém, o valor-de-troca, na figura desenvolvida do dinheiro, aparecerá como o ente subsistente e fundamental do mercado, como o ente cuja realidade da troca não se determina nem se define sem a sua presença.

\section{O dinheiro e a adoração do absoluto}

O dinheiro surge, inicialmente, na troca direta de mercadorias sob a forma de equivalente individual, como quando numa relação simples e direta de troca o linho se troca com o casaco e este lhe serve como medida individual do valor. Em seguida, supondo a troca desenvolvida, o casaco se transforma em forma equivalente particular para muitas mercadorias. Agora, nesta relação de troca, muitas mercadorias são trocadas por casaco e, nesta determinação, o casaco perde a propriedade de servir diretamente como meio de uso humano para servir como equivalente geral para várias mercadorias particulares. Em seguida, o casaco perde o posto de forma equivalente particular da riqueza para ser trocado, ele próprio, assim como todas as demais mercadorias, pelos metais preciosos.

Em sua terceira determinação, a de servir como dinheiro na forma dos metais preciosos, a mercadoria que serve como dinheiro já não mantém nenhuma relação com suas propriedades sensíveis úteis e naturais, como mantinha com o casaco. Ao contrário de quem troca mercadoria por casaco, quem troca mercadoria por dinheiro, por ouro ou prata, já não tem nenhum interesse nas propriedades sensíveis e naturais da mercadoria-dinheiro, pois ela serve agora única e exclusivamente como meio geral de troca e nada mais. Neste último movimento, a mercadoria vema-ser efetivamente dinheiro, já que os metais preciosos, como certa forma de existência da mercadoria, tornam-se a forma definitiva, perfeita e acabada do dinheiro. Nesta última determinação, ainda, os metais preciosos, agora como dinheiro, vêm-a-ser a "mercadoria excluída"

\begin{tabular}{|c|c|c|c|c|}
\hline Q Rovista Dialectus & Ano 5 & n. 12 & Janeiro - Julho 2018 & p. $139-162$ \\
\hline
\end{tabular}


[ausgeschlossene Ware] ${ }^{14}$, a "mercadoria exclusiva" [ausschließlichen Ware] ${ }^{15}$, a "mercadoria em geral” [Ware überhaupt] ${ }^{16}$, “a mercadoria” [die Ware - em itálico no original alemão] ${ }^{17}$, já que não pertence mais ao mundo da mercadoria comum, mas, sim, ao mundo da forma definitiva, perfeita e acabada da mercadoria.

Nesta fuga e exclusão do mundo, o dinheiro torna-se, então, a pura indiferença e o nada suprassensível da riqueza diante do ente sensível mercadoria. Nesta fuga, o dinheiro aparece verdadeiramente como a "encarnação individual do trabalho social" [individuelle Inkarnation der gesellschaftlichen Arbeit], como "existência autônoma do valor-de-troca” [selbständiges Dasein des Tauschwerts], como a "mercadoria absoluta" [absolute Ware] ${ }^{18}$, como a "existência absoluta do valor-de-troca" [absolutes Dasein des Tauschwerts], como a "mercadoria geral" [allgemeine Ware]"19, como a "mercadoria absolutamente alienável" [ist Geld die absolut veräußerliche Ware $]^{20}$.

Neste movimento inteiramente regido pelo princípio da negação e da abstração, o dinheiro surge como a negação da negação e a abstração de toda abstração, já que quem troca sua mercadoria sensível e concreta por dinheiro, troca uma coisa útil e concreta por uma coisa não-útil e não-concreta, troca pela coisa que é pura negação. De abstração em abstração e de superação em superação, portanto, o dinheiro, diz Marx, surge como "a mercadoria enquanto tal" [die Ware als solche], como "a mercadoria universal" [die universelle Ware], como "o representante material da riqueza universal" [der materielle Repräsentant des allgemeinen Reichtums], como "moeda mundial" [Weltmünze] indiferente a todas as suas determinações locais, sensíveis, úteis e naturais, como "a mercadoria acessível em todos os lugares" [die allerorten zugängliche Ware] e como a "figura encantada" da mercadoria [verzauberten Gestalt] ${ }^{22}$.

\footnotetext{
Para a Crítica da Economia Política, pp. 50/51. MEW 13-7, pp. 33/34.

Para a Crítica da Economia Política, pp. 50/51. MEW 13-7, pp. 33/34.

Para a Crítica da Economia Política, pp. 50/51. MEW 13-7, pp. 33/34.

Para a Crítica da Economia Política, pp. 50/51. MEW 13-7, pp. 33/34.

O Capital - Volume I, p. 115. MEW 23, p. 152.

O Capital - Volume I, p. 114. MEW 23, p. 150.

O Capital - Volume I, pp. 96/97. MEW 23, p. 124.

Karl Marx: Grundrisse: Elementos Fundamentales para la crítica de la Economia Política [borrador 1857-58]. Volume I. 15 a edição. México: 1987, p. 162. Marx Engels Werke. Band 42. Berlim: Dietz Verlag, 1983, pp. 153/154.

22 Para a Crítica da Economia Política, p. 129. MEW 13-7, pp. 127/128.
}

\begin{tabular}{|c|c|c|c|c|}
\hline Q Povista Dialectus & Ano 5 & n. 12 & Janeiro - Julho 2018 & p. $139-162$ \\
\hline
\end{tabular}


Nestas determinações inteiramente gerais e abstratas, o dinheiro se converte num ente inteiramente metafísico e sobrenatural, ele se torna "a pura abstração" [die reine Abstraktion], a “mera ilusão" [bloße Einbildung], a "mercadoria omnipresente” [allgegenwärtige Ware], "a riqueza geral em sua forma pura" [den allgemeinen Reichtum in seiner gediegnen Form], "a forma universal da riqueza" [die allgemeine Form des Reichtums], "a riqueza universal" [dem allgemeinen Reichtum], "a riqueza enquanto tal" [den Reichtum als solchen], "o deus e o rei das mercadorias" [der Gott und König der Waren]. Por este caráter universal, abstrato, suprassensível e sobrenatural da mercadoria monetária, Marx chama satiricamente o dinheiro de o Santíssimo, o Santo dos Santos [dies Allerheiligste] $]^{23}$.

A mercadoria monetária, seja ouro ou prata, adquire este caráter metafísico e extraordinário devido, em parte, pelo próprio caráter abstrato da forma dinheiro e, em parte, devido às próprias propriedades naturais dos metais preciosos. $\mathrm{O}$ ouro e a prata são, como temos visto, a forma adequada do valor de troca porque não guardam mais nenhuma relação com o caráter sensível, útil e natural da mercadoria, como guardavam mercadorias como o casaco por exemplo. Por não terem suas qualidades alteradas pela ação do tempo e da natureza, por manterem-se sempre iguais a si mesmos em todo tempo e lugar, por serem duráveis, imperecíveis e imutáveis, por serem riqueza em todos os tempos e lugares, por serem a mercadoria omnipresente, por serem o tesouro eterno da humanidade, por serem substâncias contínuas, indivisíveis e homogêneas, os metais preciosos consagram, assim, o fetiche da mercadoria como o fetiche do dinheiro.

Enquanto todas as mercadorias do mundo deterioram-se pela ação da natureza e do tempo, enquanto todas as mercadorias sofrem as dores da gênese e da morte, própria a todo ente sensível, natural e finito, o dinheiro já sai das entranhas da terra, como nota Marx, como dinheiro. Pairando acima de todos os entes fabricados pela mão humana, o dinheiro, como o Santíssimo, desce à Terra, misturando-se aos homens e às mercadorias, e retorna ao reino dos céus sem jamais deixar de ser dinheiro e igual a si mesmo. O dinheiro, por isso, ao contrário da mercadoria comum, jamais se perde e se modifica em seus movimentos pelo mundo. Ele é sempre ouro ou sempre prata em todas as partes e tempos do mundo. Com esta metafísica econômica, o mundo moderno consagra, assim, a avareza, o nihilismo e o hedonismo como a religião dos materialistas metafísicos.

23 Grundrisse I, pp. 161-169. MEW 42, pp. 153-160.

\begin{tabular}{|l|l|l|l|l|}
\hline Rovista 2 Dialectus & Ano 5 & n. 12 & Janeiro - Julho 2018 & p. 139-162 \\
\hline
\end{tabular}


Nesta nova religião, adora-se um Deus chamado ora de infinito e ora de coisa, ora de nada e ora de absoluto. Ora, ainda, chama-se este Deus pelo seu nome próprio: money, argent, Geld, Gold, ou dinheiro mesmo. Nesta nova religião adoram-se, portanto, todas as desmedidas do mundo.

Assim como na metafísica o suprassensível está separado do sensível, também no mercado o dinheiro está separado da mercadoria. Assim como na metafísica existe um ente primeiro que ordena e unifica todos os entes segundos, também no mercado existe um ente primeiro que ordena e unifica absolutamente todos os entes segundos. Assim como na metafísica o sempre eterno do mundo suprainteligível ordena e determina o sempre variável e irregular do mundo finito, natural e sensível, também no mercado o sempre eterno do mundo celestial do dinheiro ordena e determina o sempre variável e irregular do mundo finito e impuro da mercadoria. Enquanto a mercadoria comum é o bem relativo e passageiro da realidade, o dinheiro vem-a-ser o summun bonum ${ }^{24}$ do mercado, diz Marx.

Assim, como podemos perceber, todas as relações metafísicas entre o sensível e o suprassensível encontradas no saber filosófico e religioso podem facilmente transpor-se analogicamente para o estudo das relações entre a mercadoria e o dinheiro. Enquanto a mercadoria aparece como o ens creatum e o secundum ens do mercado, o dinheiro aparece como o summum ens, como o ens increatum, como o primum ens do mercado. O dinheiro, por isso, é o absoluto transubstanciado no corpo de uma peça metálica. É o esse divinum do mercado. É o esse commune entre as mercadorias. É o actus essendi do mercado. É aquele ente que pela sua perfeição fora excluído do mundo imperfeito da mercadoria e que agora habita a morada do ser. É aquele ente primeiro e fundador da realidade que agora ordena e determina os entes fundamentados por ele. $\mathrm{O}$ dinheiro é a perfeição excluída do mundo. É aquele ente atual supremo e perfeito que não recebe nem pode receber qualquer adição à sua atualidade e perfeição. O dinheiro é o telos supremo e o ato final das mercadorias, é a atualidade de todos os atos e a perfeição de todas as coisas perfeitas. Os entes da riqueza natural, os entes deste mundo carente de perfeição, os entes que habitam o mundo da potência, desejam ardentemente ultrapassar seu próprio mundo impuro e imperfeito habitando o mundo puro e perfeito da riqueza abstrata transubstanciando-se em dinheiro. Nesta transubstanciação, os entes da riqueza utilizável e manipulável são convertidos naqueles entes

24

Para a Crítica da Economia Política, p. 125. MEW 13-7, p. 122.

\begin{tabular}{|l|l|l|l|l|}
\hline Qenista Dialectus & Ano 5 & n. 12 & Janeiro - Julho 2018 & p. 139-162 \\
\hline
\end{tabular}


sacrossantos sem serventia ao uso humano que se amontoam uns sobre os outros no depósito dos bancos.

Com essa transubstanciação [Transsubstantiation] ${ }^{25}$ da mercadoria em dinheiro, com essa materialização de trabalho humano [Materiatur menschlicher Arbeit] ${ }^{26}$, com essa materialização social absoluta da riqueza em geral [absolut gesellschaftliche Materiatur des Reichtums überhaupt $]^{27}$ no corpo dos metais preciosos, com essa objetivação da riqueza abstrata e geral da humanidade no corpo de um ente singular, de um corpo singular que é ao mesmo tempo um corpo universal, o fetiche do dinheiro [Geldfetischs] vem-a-ser o fetiche da mercadoria [Warenfetischs] tornado visível e ofuscante ${ }^{28}$, diz Marx.

Por seu caráter de ser excluído e perfeito, por seu caráter de ser unívoco em meio a equivocidade dos entes, o dinheiro é o ser analógico do mercado, é aquele ser intermediário, é aquele ser ao mesmo tempo unívoco e equívoco, é aquele ser supremo que ao traficar livremente pelo mundo reúne e supera em sua univocidade a equivocidade da mercadoria. Por ser a mercadoria excluída, por ser o ente analógico do mercado, a sacroessencialidade do dinheiro está contida, por isso, também, em proporções diversas, na mundanoessencialidade da mercadoria comum. $\mathrm{O}$ dinheiro é aquele ente supremo que em sua unidade encarna toda a multiplicidade e diversidade do mundo da mercadoria, pois o dinheiro mesmo é a mercadoria perfeita excluída. O dinheiro é aquela mercadoria excluída e ao mesmo tempo desejada pelo mundo da mercadoria comum.

No dinheiro a essencialidade suprassensível e divina da riqueza é plena e perfeita. $\mathrm{Na}$ mercadoria ela é precária e imperfeita. O dinheiro é o modo de ser pleno e perfeito da mercadoria. Por isso o ente mercadoria ama e deseja o ente dinheiro da mesma maneira que o crente ama e deseja o Imolado de Deus. O dinheiro é o ser imolado do mercado, é aquele corpo que por seu caráter moral, sagrado e perfeito fora excluído do mundo da mercadoria comum e entregue para viver como um deus, mas, que, contraditoriamente e ao mesmo tempo, é desejado e venerado por esta mesma comunidade que o excluiu.

No dinheiro, na mercadoria monetária ouro, a supraessencialidade do ente pleno e perfeito da riqueza é imediatamente idêntica e adequada à sua existência. No ente ouro, o sensível e

25 O Capital - Volume I, p. 95. MEW 23, p. 122.

O Capital - Volume I, p. 57. MEW 23, p. 67.

O Capital - Volume I, pp. 118/119. MEW 23, p.156. Em inglês no original alemão.

O Capital - Volume I, p. 85. MEW 23, pp. 107/108.

\begin{tabular}{|l|l|l|l|l|}
\hline Q Rovista Dialectus & Ano 5 & n. 12 & Janeiro - Julho 2018 & p. 139-162 \\
\hline
\end{tabular}


o suprassensível se encontram e se reconciliam entre si. Na mercadoria comum, ao contrário, persiste a inadequação e diferença entre ser e existência. A mercadoria é potência para ser dinheiro. $\mathrm{O}$ dinheiro, porém, é atualidade do ato. $\mathrm{O}$ ente dinheiro é a infinita abundância da riqueza. $\mathrm{O}$ ente mercadoria, ao contrário, é a abundância finita da riqueza e só parcialmente é dinheiro, pois é dinheiro somente em potência. Uma vez consumida pelo uso humano ela desaparece do mundo. Para ser dinheiro e ser eternamente ela precisa, por isso, ser trocada e transubstanciada.

O ente dinheiro, por ser o ente transcendente do mercado, por ser o ente excluído do mundo da mercadoria, por ser ato pleno que transborda o mundo imperfeito da potência, jamais desaparece do mundo, jamais se acaba e se consome neste mundo. Ele é dinheiro e, por isso, riqueza plenamente abundante e infinitamente eterna. Os entes da riqueza finita desejam, por isso, participar desta infinita abundância de ser própria ao ente dinheiro, traficando com ele, metamorfoseando-se nele e, assim, com ele se adequando e se identificando. Nesta exclusão do universo do ente sensível mercadoria, nesta fuga e transcendência do mundo, neste transbordamento imanente à supraessencialidade do dinheiro, o ente dinheiro torna-se o ente pleno, perfeito e absoluto do mercado mundial.

Para o mundo capitalista, riqueza é dinheiro e dinheiro propriamente dito é a peça metálica ouro. As outras coisas são dinheiro de maneira imprópria, inadequada e imperfeita. De todas estas coisas a mais inadequada e imperfeita é o ente mercadoria, é aquele ente sensível que possui valor de uso imediato para o ente humano. A peça metálica ouro é dinheiro e riqueza propriamente ditos porque é o único ente que circula e é aceito como tal em todas as partes do mundo. A moeda de cunho forçado é dinheiro de maneira imperfeita porque só circula e só é aceita dentro dos marcos nacionais. A mercadoria comum, ainda que circule livremente pelo mundo como o ente ouro, é riqueza de maneira imprópria e inadequada porque não pode ser guardada e acumulada, porque se destina ao uso e satisfação de uma necessidade humana.

Deste modo, assim como nos domínios da metafísica a entidade de um ente se define a partir de sua relação com o abstrato e o suprassensível, sendo mais ente e mais substância o ente proporcionalmente mais próximo do suprassensível e mais distante do sensível, também nos domínios da riqueza as coisas serão mais ou menos riqueza na mesma medida em que serão mais ou menos dinheiro. A supraessencialidade do dinheiro, por isso, definirá e servirá de medida modelar para definir e medir a essencialidade de todos os outros entes da realidade.

\begin{tabular}{|c|c|c|c|c|}
\hline Rovista Dialectus & Ano 5 & n. 12 & Janeiro - Julho 2018 & p. $139-162$ \\
\hline
\end{tabular}


Como a negação de tudo o que é determinado e de tudo o que existe numa forma útil e natural, o dinheiro transforma, assim, seu possuidor, em homem universal e abstrato, em cidadão do mundo, naquele que está em "possessão do que está privado de individualidade" [Besitz des Individualitätslosen] $]^{29}$. A posse e o vínculo com esta "coisa que não está conectada de modo algum com sua individualidade" [diese Beziehung zu einer gar nicht mit seiner Individualität zusammenhängenden Sache], confere, ao mesmo tempo, ao indivíduo, “o domínio absoluto sobre a sociedade" [die allgemeine Herrschaft über die Gesellschaft] ${ }^{30}$. O poder do dinheiro oferece, ainda, ao indivíduo, um poder geral sobre todo o "mundo dos gozos e prazeres" [Welt der Genüsse $]^{31}$. O poder universal do dinheiro permite, deste modo, ao indivíduo, viver uma vida inteiramente desregrada e desmedida, experimentando todos os prazeres e gozos possíveis, permite a ele viver uma vida sem finalidade e dedicada exclusivamente ao ócio e ao hedonismo sem limites.

Deste modo, assim como deus na religião cristã é fonte ilimitada de virtudes e abundância infinita de amor, assim também o dinheiro na religião do mercado é fonte ilimitada de pecados e abundância infinita de prazer. O dinheiro, por isso, é o deus da religião do prazer. Ele também é o deus da religião da avareza. Enquanto o hedonista deseja se apoderar das forças infinitas do dinheiro para gastá-las, o avarento deseja apoderar-se destas forças para guarda-las, empilhá-las e admirá-las. Ambos vivem, em comum, uma vida dedicada à arte do dinheiro.

Com o surgimento da riqueza em sua forma universal surgem, assim, a avareza, $[\mathrm{Geiz}]^{32}$, a sede abstrata por riqueza [abstrakte Genußsucht $]^{33}$, a ambição por dinheiro [Geldgier ${ }^{34}$, a ganância [Habsucht $]^{35}$, a cobiça por riqueza [Bereicherungssucht $]^{36}$ e a sede de prazeres em sua forma geral [Genußsucht in ihrer allgemeinen Form $]^{37}$. O hedonismo e o nihilismo da filosofia e da literatura modernas têm, por isso, segundo Marx, não apenas seu objeto [Gegenstand] ${ }^{38}$, mas,

Grundrisse I, p. 157. MEW 42, p. 148.

Grundrisse I, p. 156. MEW 42, p. 149.

Grundrisse I, p. 156. MEW 42, p. 149.

Grundrisse I, p. 157. MEW 42, p. 149.

Grundrisse I, p. 157. MEW 42, p. 149.

Grundrisse I, p. 157. MEW 42, p. 149.

Grundrisse I, p. 157. MEW 42, p. 149.

Grundrisse I, p. 157. MEW 42, p. 149.

Grundrisse I, p. 157. MEW 42, p. 149.

Grundrisse I, p. 157. MEW 42, p. 149.

\begin{tabular}{|l|l|l|l|l|}
\hline Q Rovista Qialectus & Ano 5 & n. 12 & Janeiro - Julho 2018 & p. 139-162 \\
\hline
\end{tabular}


sobretudo, sua fonte [Quelle] ${ }^{39}$ numa coisa humana chamada dinheiro e, de modo algum, na natureza e nas paixões humanas.

Como diz Marx, “o dinheiro é não apenas o objeto, mas, ao mesmo tempo, a fonte da sede de enriquecimento" [Das Geld ist also nicht nur der Gegenstand, sondern zugleich die Quelle der Bereicherungssucht $]^{40}$. Esta vontade de nada do mundo moderno se resume, no fundo, a uma vontade por dinheiro, a uma vontade por todas as coisas indeterminadamente, pois o dinheiro é o ser-nada do mundo, é o nada indeterminado da riqueza humana, o nada da riqueza que não é um algo, da riqueza que não é nada determinado, mas que pode vir-a-ser, paradoxalmente, toda a riqueza, da riqueza que é riqueza simplesmente.

Por isso, para o avarento capitalista, o apego apaixonado pela riqueza sensível e particular, pela mercadoria em geral, equivale a apaixonar-se pelas coisas passageiras e perecíveis do mundo. Para ele, como na metafísica e na crença cristã, o apego verdadeiro deve ser aquele apego às coisas imperecíveis e duráveis, às coisas que não estão submetidas ao eterno devir da natureza, às coisas que se mantêm sempre idênticas e iguais a si mesmas em qualquer tempo e espaço, à coisa contínua, indivisível, homogênea e permanente que chamamos dinheiro.

Ao apegar-se ao dinheiro como uma coisa permanente, imperecível, durável, contínua, indivisível, homogênea e eterna, o avarento apega-se, em sua crença, assim, a uma coisa equivalente a Deus. Ao dirigir sua paixão exclusivamente para o dinheiro, ao amar exclusivamente um único e mesmo deus, o avarento capitalista acredita salvar sua alma, assim, do dilaceramento próprio às paixões passageiras do mundo humano. Sua devoção ao dinheiro equivale, assim, em sua imaginação, à devoção ao suprassensível e a Deus. Nesta devoção, o monoteísmo de sua crença se conserva sempre igual, seja amando o Dinheiro, seja amando a Deus.

\section{Feuerbach e a crítica da metafísica religiosa}

Nada na linguagem filosófica de Marx parece dizer que seria a mercadoria comum aquela que estaria encarnada por um espírito sedutor e demoníaco e que despertaria no homem os desejos mais insanos, absurdos, violentos e irrefreáveis. A mercadoria que, segundo Marx, despertaria, e desperta efetivamente, as mais absurdas e irrefreáveis formas de violência humana é a

39 Grundrisse I, p. 157. MEW 42, p. 149.

$40 \quad$ Grundrisse I, p. 157. MEW 42, p. 149.

\begin{tabular}{|l|l|l|l|l|}
\hline Qevista Dialectus & Ano 5 & n. 12 & Janeiro - Julho 2018 & p. 139-162 \\
\hline
\end{tabular}


mercadoria especial chamada dinheiro. Por isso, o fetiche do ente mercadoria é, sobretudo, o fetiche da mercadoria absoluta chamada dinheiro.

Como sabemos, na religião cristã o mundo aparece metafisicamente duplicado: de um lado aparece o mundo sensível e terreno das relações humanas e acima dele aparece o mundo suprassensível do Deus-pessoa e da fé. Como sabemos desde Feuerbach, os louvores cristãos aos poderes de Deus-pessoa não passam de louvores invertidos e alienados das potências e características humanas do homem. Essa mesma duplicidade metafísica está, agora, instalada na esfera humana da riqueza. De um lado, temos a atividade sensível e criadora do trabalho humano e, acima dela, a esfera das trocas e do ente dinheiro. Como o Deus-pessoa da crença cristã, o ente dinheiro atua como ente autonomizado e independente dos homens, pairando acima de suas consciências e submetendo-os a seus próprios poderes alienados.

Nessa inversão, o ente dinheiro não aparece como resultado do processo de troca e mera criatura do mundo da mercadoria, mas como o verdadeiro demiurgo e criador da realidade. Nessa metafísica, o ente dinheiro não aparece como objetivação e representação alienada das forças genéricas, abstratas e sociais da produção, mas como sua mais autêntica e fundamental força sobrenatural. Como força sobrenatural da produção, o dinheiro aparenta ser tão ou mais fundamental para a produção da riqueza que todos os seus elementos verdadeiramente naturais como a terra, o trabalho e os instrumentos de trabalho. Desse modo, nada mais parece possível de ser fabricado sem o ente dinheiro.

Marx chama de fetiche da mercadoria o processo através do qual o ente dinheiro se põe no mundo acima e à frente dos homens como uma potência estranha e dominadora inteiramente objetiva e autônoma, como uma coisa externa à realidade humana e sem nenhuma relação com o trabalho e a atividade sensível e criadora do trabalhador, como o verdadeiro demiurgo da realidade.

$\mathrm{Na}$ história da metafísica e da religião cristã, o abstrato e indeterminado, que por natureza é invisível aos sentidos humanos, aparece sempre efetivado, encarnado, corporificado e visível no corpo de um elemento sensível. Na religião cristã, o Deus abstrato aparece encarnado, aparece objetivado como pessoa, como corpo visível na figura do Cristo, na figura de um homem singular e sensível. Assim também ocorre com o fetiche da mercadoria, onde o valor da coisa, o abstrato e indeterminado dela, o invisível aos sentidos dos agentes da troca, aparece objetivado na figura de um corpo sensível, na figura da forma equivalente geral, na figura dos metais preciosos e

\begin{tabular}{|c|c|c|c|c|}
\hline Qenista Oialectus & Ano 5 & n. 12 & Janeiro - Julho 2018 & p. $139-162$ \\
\hline
\end{tabular}


da forma dinheiro. Da mesma maneira que na metafísica e na religião cristã, também na vida cotidiana das trocas os agentes vivos e reais do processo tomam o não vivo e o não real, tomam o objetivado, o abstrato e o não útil, como o efetivamente real, como a encarnação e a concretização do verdadeiramente real, desprezando, escarnecendo e alienando, por consequência, o que de verdadeiramente útil e real carregam em suas mãos.

Assim como na metafísica e na religião cristã o abstrato e o encarnado aparecem como o efetivamente real, como o que efetivamente possui valor e deve ser guardado, idolatrado e considerado pelo homem, também na metafísica das trocas o dinheiro aparece como o abstrato, o encarnado e o efetivamente real, que deve ser guardado, protegido e idolatrado pelo homem. Como na metafísica religiosa, na metafísica econômica o não encarnado é visto como coisa de menor valor e insignificância ontológica, como coisa de menor ser, essência, verdade e realidade.

Analogamente à religião cristã, os agentes da troca louvam suas próprias capacidades físicas e humanas, suas capacidades sensíveis para o trabalho, como capacidades de entes suprassensíveis, divinos, autonomizados e independentes deles. Por esse culto econômico da riqueza em sua forma metafísica e abstrata, da riqueza em sua forma dinheiro, o cristianismo, diz $\operatorname{Marx}^{41}$, especialmente sua versão protestante, com seu culto do homem abstrato [Kultus des abstrakten Menschen], é a forma de religião mais adequada às instituições econômicas do capitalismo.

Como temos mostrado, a religião à qual Marx sempre se refere na análise do fetichismo da mercadoria não é a religião natural do panteísmo, mas a religião cristã, a religião revelada e do deus-pessoa fundada na ideia de um aquém separado do além. Nesta religião, o aquém é a morada mundana do homem enquanto o além é a morada divina do absoluto. Por este motivo, compreenderemos melhor o fetiche da mercadoria fazendo um paralelo com a análise crítica do fetiche da religião desenvolvida por Feuerbach:

A religião, pelo menos a cristã, diz Feuerbach, é o relacionamento do homem consigo mesmo ou, mais corretamente, com a sua essência, mas o relacionamento com a sua essência como uma outra essência. A essência divina não é nada mais do que a essência humana, ou melhor, a essência do homem abstraída das limitações do homem individual, isto é, real, corporal, objetivada, contemplada e adorada como uma outra essência própria,

41 O Capital - Volume I, p. 75. MEW 23, p. 93.

\begin{tabular}{|c|c|c|c|c|}
\hline Qevista Dialectus & Ano 5 & n. 12 & Janeiro - Julho 2018 & p. $139-162$ \\
\hline
\end{tabular}


diversa da dele. Por isso, diz Feuerbach, todas as qualidades da essência divina são qualidades da essência humana. ${ }^{42}$

De maneira paralela, podemos dizer, seguindo Feuerbach, então, que:

O dinheiro é o relacionamento do homem consigo mesmo ou, mais corretamente, com a sua essência objetivada, com a sua essência como se fosse uma outra essência. A essência do dinheiro é nada mais do que a essência humana objetivada, ou melhor, a essência do homem abstraída das limitações do homem individual, isto é, real, corporal, objetivada, contemplada e adorada como se fosse uma outra essência, estranha e diversa da dele. Por isso, podemos afirmar, todas as qualidades visíveis da essência monetária são projeções e objetivações das qualidades invisíveis da essência humana.

Feuerbach desvela completamente os mistérios supostamente indecifráveis da religião invertendo a inversão metafísica. A metafísica inverte os polos da relação entre o homem e deus na medida em que transforma o predicado deus em essência do homem e a substância homem em mero predicado desta essência invertida. A inversão crítica de Feuerbach consiste em inverter a inversão religiosa pondo o homem como homem e sujeito da criação e deus como deus e mero predicado, projeção e criatura do sujeito criador homem. A mercadoria, do mesmo modo que na religião, inverte a relação entre homem e dinheiro na medida em que encontra no dinheiro a essência do homem e no homem um mero predicado e portador da essência. Assim como sem a essência deus o homem não é homem, assim como afastado desta essência o homem não é, do mesmo modo ocorre no mundo da mercadoria, onde o homem afastado do dinheiro não é. A inversão crítica de Marx consiste em inverter a inversão monetária pondo o homem como homem e sujeito da criação e o dinheiro como dinheiro e mero predicado, projeção, objetivação e criação do sujeito homem.

Os louvores do mundo moderno ao ente dinheiro não passam, por isso, segundo nosso entendimento acerca da análise de Marx, de louvores invertidos e mistificados das potencialidades humanas genéricas, abstratas, físicas e intelectuais para o trabalho, não para este ou aquele trabalho concreto, útil e determinado, mas para o humano enquanto tal, agora objetivadas numa peça metálica. Ainda que de maneira fetichizada e mistificada, ao louvar as capacidades universais do ente dinheiro, os agentes da troca louvam na verdade sua própria essência e capacidades genéricas para o trabalho. Os louvores sacerdotais do mundo moderno ao ente dinheiro, por isso, não passam

42 Ludwig Feuerbach. A essência do cristianismo. Campinas S.P: Papirus, 1988, p. 57.

\begin{tabular}{|c|c|c|c|c|}
\hline Revista Dialectus & Ano 5 & n. 12 & Janeiro - Julho 2018 & p. $139-162$ \\
\hline
\end{tabular}


de louvores ao trabalho genérico do homem, à essência genérica do homem, em sua figura objetivada, alienada e fetichizada.

\section{A existência do absoluto como coisa da mão humana}

O surgimento do dinheiro como ente absoluto resolve, assim, uma das mais complexas, misteriosas e controversas questões da metafísica e da theologia, a questão metafísica por excelência: a da atribuição de existência, efetiva e real, ao absoluto. Com o dinheiro o absoluto torna-se, assim, não apenas um mero conceito, sentimento ou ideia, mas uma verdadeira realidade. O absoluto, agora, existe, é um ente, todos podem vê-lo, tocá-lo e guardá-lo em seus bolsos. Por esse motivo, o comportamento do filósofo metafísico, o do religioso cristão e o do homem econômico podem ser aproximados entre si da seguinte maneira. O metafísico é aquele que, como o Tales retratado na anedota contada pela escrava trácia, indiferente às coisas triviais do mundo sensível e da vida cotidiana, às coisas mais elementares, rotineiras e imediatas da vida, vivia de cabeça erguida para o céu contemplando o divino, o distante, o absoluto, o inalcançável, o abstrato, o indeterminado da realidade e tropeçava diariamente nos buracos da realidade que se abriam à sua frente. O metafísico é aquele que considera como essencial, efetivo, verdadeiro e real o abstrato e indeterminado da realidade, é aquele que só tem vistas para o suprassensível da realidade, relegando à natureza e ao sensível o escárnio, o desprezo e a indiferença próprios do não essencial, do não efetivo e do não verdadeiro.

O metafísico é aquele que divide o mundo em dois domínios e regiões. De um lado está o sensível, o não essencial e não verdadeiro, e de outro está o suprassensível, o essencial e verdadeiro. Para o metafísico, o sensível é o visível enquanto o suprassensível é o invisível. Para o metafísico, o essencial e verdadeiro é o invisível, o suprassensível, o abstrato e indeterminado das ideias só alcançadas pela atividade do pensamento. O não essencial e não verdadeiro é o visível, o sensível, o concreto e determinado da vida natural e material. Para o metafísico, o visível e o sensível só se tornam reais e efetivos na medida em que participam do invisível e do suprassensível, do abstrato e do indeterminado, das ideias e do pensamento. Para o metafísico, o invisível e o suprassensível são sempre o fundamento e a arkhé de toda a realidade, são sempre a essência e a substância, são sempre aquilo que subjaz eternamente imóvel e perfeito por baixo de toda a realidade visível, sensível e não substancial sustentando-a e tornando-a possível e real.

\begin{tabular}{|l|l|l|l|l|}
\hline Q Revista Dialectus & Ano 5 & n. 12 & Janeiro - Julho 2018 & p. 139-162 \\
\hline
\end{tabular}


Na Religião Judaico-Cristã, o metafísico é aquele que acredita ora no Deus pessoal invisível, suprassensível, abstrato, indeterminado e separado da realidade, ora no Deus pessoal visível, sensível e encarnado na figura do Cristo, na figura de um homem, de um corpo natural sensível e determinado. Como todo metafísico, o religioso abandona e despreza a vida real, a vida sensível e imediata, a vida que ele efetivamente possui, a vida no aquém, para viver e amar uma vida que ele efetivamente não possui, mas imagina um dia possuir, no pós-morte, no além, na vida da eternidade. Como todo metafísico, o religioso escarnece, abandona e renega a natureza e a vida sensível, os amigos, os amores, as paixões, os homens sensíveis que efetivamente possui ao seu lado, para viver ao lado de vidas e de entes, de deuses, de almas, de anjos e arcanjos, que só existem no além da vida e no estranhamento de sua imaginação religiosa.

Na economia, o metafísico é o guardião do dinheiro e empresário capitalista, é aquele que, como todo metafísico, busca desesperadamente pelo absoluto, busca louca e apaixonadamente se apoderar do abstrato e do indeterminado da realidade. Para o filósofo, o absoluto é sempre uma ideia ou pensamento abstrato e indeterminado, distante do visível e do sensível, é o suprassensível visível somente para o pensamento. Dada sua natural incapacidade para apreender o inapreensível, o filósofo aceita passivamente o destino infeliz de ser um mero amante e contemplador do abstrato, um mero guardião no pensamento do absoluto e efetivo da realidade. Para o religioso judaicocristão, o absoluto é Deus, ora é o Deus abstrato do judaísmo, alienado e separado da realidade dos homens, ora é o Deus encarnado na figura do Cristo, também ele, após a morte, ressurreição e retorno ao céu, alienado e separado da vida humana.

Enquanto o judeu adora o abstrato e alienado do céu, o cristão adora sua encarnação humana e sua representação na forma de coisas sensíveis e estranhas ao perfeito e ao divino contidos no abstrato, como os pregos e a madeira da cruz. Para o empresário capitalista e guardião do dinheiro, o absoluto é o dinheiro, é a riqueza abstrata e indeterminada dos metais preciosos, é o poder criador geral da humanidade encarnado na materialidade dos metais preciosos. Enquanto o filósofo e o religioso se ocupam e se contentam apenas com a guarda e a contemplação mística do absoluto, um no pensamento e o outro no coração, o empresário capitalista pretende guardar e contemplar o absoluto em seu bolso, em seu cofre e em seu tesouro. Enquanto o filósofo pretende encher o espírito com a sabedoria e o pensamento do absoluto e o religioso encher o coração com a

\begin{tabular}{|c|c|c|c|c|}
\hline Q Rovista Dialectus & Ano 5 & n. 12 & Janeiro - Julho 2018 & p. $139-162$ \\
\hline
\end{tabular}


magia e a bondade mística de Deus, o empresário capitalista pretende encher o bolso com o vil metal.

Enquanto a metafísica do filósofo é a metafísica do pensamento e a do religioso é a do sentimento, a metafísica do empresário capitalista é a metafísica do desejo e da paixão. Entre todos eles reina o mesmo amor e o mesmo apego pelo abstrato, pelo indeterminado e pelo absoluto. Entre todos eles reina, ainda, o mesmo escárnio, o mesmo desapego, o mesmo desprezo e a mesma indiferença pela vida real e efetiva, pelo finito, pelo sensível, pela natureza e pela espécie humana. Entre todos eles reina o mesmo princípio, o mesmo princípio da negatividade e da abstração, o mesmo princípio do amor incondicional, do apego exagerado, da guarda sem limites e da paixão irracional pelo não verdadeiro, pelo não efetivo e pelo não real da realidade humana. Entre todos eles reina o mesmo princípio do amor insano e desmedido pelo absoluto da realidade, por aquilo do qual, em sua pobre imaginação metafísica, emanaria toda a vida e todo o sentido da existência humana. Para todos eles, a existência humana efetiva, a existência humana trágica e dolorosa, a existência humana natural, sensível e efetiva, a existência deste ente humano João, Pedro e Maria singulares, é uma existência falsa e não verdadeira. Para todos eles, a verdadeira existência humana é considerada a existência ao lado do absoluto: das ideias, do deus e do dinheiro.

Enquanto para o homem ordinário, o fundamental e efetivo da realidade é o finito, o sensível, o mutável, o natural, o visível, o imperfeito, o incompleto e o trágico, para o metafísico, para este homem invertido, irreal, abstrato, cindido, estranhado e desnaturado pelo absoluto, o real e efetivo é o infinito, o suprassensível, o imutável, o não natural e o abstratamente perfeito e completo. A metafísica da mercadoria produz, deste modo, um assustador desinteresse humano pelo mundo do aquém, pelo mundo natural e sensível, pela poesia, a representação, a qualidade, a essência e o útil e por um gosto e um interesse unicamente pelo além, pelo ente negativo, abstrato, numérico, não útil e calculável do mundo. Entre o filósofo, o religioso e o empresário capitalista domina, assim, a mesma consciência insana de querer guardar para si aquilo que é de natureza universal e geral, de querer para si aquilo que está para além de todo si, de todo querer e de todo homem em seu sentido abstrato, singular e imediato.

\section{REFERÊNCIAS}

\begin{tabular}{|c|c|c|c|c|}
\hline Q Rovista Dialectus & Ano 5 & n. 12 & Janeiro - Julho 2018 & p. $139-162$ \\
\hline
\end{tabular}


FEUERBACH, Ludwig. A essência do cristianismo. Campinas S.P: Papirus, 1988.

MARX, Karl. Para a crítica da economia política. Coleção: Os Pensadores. São Paulo: Nova Cultural, 1987.

O Capital: crítica da economia política. Livro I. Volume I. Tradução de Regis Barbosa e Flávio R. Kothe. $3^{a}$ edição. São Paulo: Nova Cultural, 1988.

Grundrisse: elementos fundamentales para la crítica de la economia política [borrador 1857-58]. Volume I. 15 edição. México: 1987.

\begin{tabular}{|l|l|l|l|l|}
\hline Govista & Ano 5 & n. 12 & Janeiro - Julho 2018 & p. 139-162 \\
\hline
\end{tabular}

